\title{
EFEKTIFITAS TERAPI RELAKSASI BENSON TERHADAP TEKANAN DARAH PADA PENDERITA HIPERTENSI
}

\author{
Joko Tri Atmojo', Made Mahaguna Putra ${ }^{2}$, Ni Made Dewi Yunica Astriani², Putu \\ Indah Sintya Dewi ${ }^{2}$, Tjahja Bintoro ${ }^{4}$ \\ ${ }^{1}$ Sekolah Tinggi Ilmu Kesehatan Mamba'ul Ulum Surakarta, Jawa Tengah \\ ${ }^{2}$ Sekolah Tinggi Ilmu Kesehatan Buleleng, Bali \\ ${ }^{3}$ International Nursing Training Center Bali, Bali \\ ${ }^{4}$ Akademi Keperawatan dr. Soedono Madiun, Jawa Timur
}

\begin{abstract}
Background: Hypertension is associated with an increase in systolic pressure or diastolic pressure, or the pressure of both. Hypertension is defined as persistently high blood pressure where the systolic pressure above $140 \mathrm{mmHg}$ and diastolic pressure above $90 \mathrm{mmHg}$. One of the non-pharmacological treatments for hypertension is with benson relaxation therapy. The purpose of this research was to analyze the effect of benson relaxation therapy towards blood pressure in patients with hypertension in Unggahan Village. Method: The research design was pra-experimental design with one group pre-post test design. The research sample consisted of 30 people. The sampling technique used non probability sampling with techniques purposive sampling and data from respondents was collected by using a digital tensimeter measuring instrument. This study used Paired t-test examination significant standard $\alpha=0.05$. Result: The result of study shows that before was given a benson relaxation therapy that was Mean systolic blood pressure is 149.93, and Mean diastolic blood pressure is 89.33. Then, after given a benson relaxation therapy that was Mean systolic blood pressure is 138.97 and Mean diastolic blood pressure is 84.07. The results of examination Paired t-test, it obtained the score $p$ pre and post $(0,000)<\alpha(0,05)$, which means that $H_{0}$ is ferected and $H_{a}$ accepted. Conclusion: Thus, it can be conclude that there is effect of benson relaxation therapy towards blood pressure in patients with hypertension in Unggahan Village.
\end{abstract}

Keywords: Hypertension, Benson Relaxation Therapy, Blood Pressure

\section{PENDAHULUAN}

Hipertensi merupakan suatu keadaan dimana seseorang mengalami peningkatan pada tekanan darah di atas normal yang menyebabkan terjadinya peningkatan angka morbiditas (kesakitan) dan angka mortalitas (kematian) (Aspiani, 2014). Hipertensi adalah suatu keadaan dimana tekanan darah meningkat secara abnormal dan terjadi secara terus menerus pada beberapa kali pemeriksaan tekanan darah yang disebabkan oleh satu faktor maupun beberapa faktor risiko yang tidak berjalan sebagaimana mestinya dalam mempertahankan tekanan darah secara normal (Wijaya \& Putri, 2013).

Hasil survei yang dilakukan oleh World Health Organization (WHO), pada tahun 2012 jumlah kasus hipertensi di dunia adalah 839 juta dan diperkirakan akan semakin meningkat pada tahun 2025 dengan jumlah kasus hipertensi yaitu 1,15 milyar, sekitar $29 \%$ dari total penduduk di dunia (Larasiska \& Priyantari, 2017). 
Berdasarkan pada hasil pengukuran tekanan darah, prevalensi hipertensi pada usia 18 tahun ke atas pada tahun 2007 di Indonesia yaitu sebesar $31,7 \%$. Menurut provinsi, prevalensi hipertensi paling tinggi yaitu di provinsi Kalimantan Selatan (39,6\%), Kalimantan Timur $(29,6 \%)$, Jawa Barat $(29,4 \%)$, Bali $(19,9 \%)$. Sedangkan bila dibandingkan pada tahun 2013 terjadi penurunan sebanyak 5,9\% (dari 31,7\% menjadi $25,8 \%$ ). Penurunan ini bisa terjadi karena berbagai macam faktor yaitu seperti: alat pengukuran tekanan darah yang berbeda, masyarakat yang sudah mulai sadar dengan bahaya penyakit hipertensi. Prevalensi hipertensi di Indonesia yang didapatkan melalui kuesioner terdiagnosis oleh tenaga kesehatan sebanyak 9,4\%, yang didiagnosis tenaga kesehatan atau yang sedang minum obat sebesar $9,5 \%$. Sehingga, ada $0,1 \%$ yang minum obat sendiri. Selanjutnya gambaran pada tahun 2013 dengan menggunakan unit analisis individu menunjukkan bahwa secara nasional penduduk Indonesia yang menderita penyakit hipertensi sebanyak $25,8 \%$. Jika saat ini penduduk di Indonesia sekitar 252.124.458 jiwa maka terdapat 65.048 .110 jiwa yang menderita hipertensi (Kemenkes, 2014).

Salah satu terapi non farmakologi dalam menurunkan tekanan darah yaitu dengan teknik relaksasi. Dengan metode relaksasi dapat mengontrol sistem saraf yang bermanfaat untuk menurunkan tekanan darah (Suiraoka, 2012). Konsep dasar teknik relaksasi pada hakekatnya cara relaksasi yang diperlukan untuk menurunkan ketegangan pada otot yang dapat memperbaiki denyut nadi, tekanan darah, dan pernafasan (Aspiani, 2014). Teknik relaksasi saat ini terus dikembangkan menjadi beberapa teknik, salah satunya yaitu relaksasi benson. Relaksasi benson merupakan metode teknik relaksasi yang diciptakan oleh Herbert Benson, seorang ahli peneliti medis dari Fakultas Kedokteran Harvard yang mengkaji beberapa manfaat doa dan meditasi bagi kesehatan. Relaksasi benson yaitu salah satu teknik relaksasi yang sederhana, mudah dalam pelaksanaannya, dan tidak memerlukan banyak biaya. Relaksasi ini merupakan gabungan antara teknik respon relaksasi dengan sistem keyakinan individu atau faith factor. Fokus dari relaksasi ini pada ungkapan tertentu yang diucapkan berulang-ulang dengan menggunakan ritme yang teratur disertai dengan sikap yang pasrah. Ungkapan yang digunakan dapat berupa nama-nama Tuhan atau kata-kata yang memiliki makna menenangkan untuk pasien itu sendiri (Solehati \& Kosasih, 2015).

Cara kerja teknik relaksasi benson ini yaitu berfokus pada kata ataupun kalimat tertentu yang diucapkan berulang kali dengan ritme teratur yang disertai dengan sikap pasrah kepada Tuhan Yang Maha Esa sambil menarik nafas dalam. Pernafasan yang panjang akan memberikan energi yang cukup, karena pada waktu menghembuskan nafas mengeluarkan karbondioksida $\left(\mathrm{CO}_{2}\right)$ dan pada saat menghirup nafas panjang mendapatkan oksigen yang sangat membantu tubuh dalam membersihkan darah dan mencegah kerusakan jaringan otak akibat kekurangan oksigen (hipoksia). Saat menarik nafas panjang otot pada dinding perut (rektus abdominalis, transverses abdominalis, internal dan ekternal obligue) akan menekan iga bagian bawah ke arah belakang serta mendorong sekat diafragma ke atas dapat menyebabkan 
tingginya tekanan intra abdominal, sehingga dapat merangsang aliran darah baik vena cava inferior ataupun aorta abdominalis, yang menyebabkan aliran darah (vaskularisasi) meningkat keseluruh tubuh terutama pada organ-organ vital seperti otak, sehingga $\mathrm{O} 2$ tercukupi di dalam otak dan tubuh akan menjadi rileks (Maulinda, Candrawati, \& Adi W, 2017).

Pada saat keadaan relaksasi menyebabkan penurunan rangsangan emosional dan penurunan rangsangan pada area pengatur fungsi kardiovaskular seperti hipotalamus posterior yang akan menurunkan tekanan darah, sedangkan rangsangan pada area pre optik menimbulkan efek penurunan arteri dan frekuensi denyut jantung yang dijalarkan melalui pusat kardiovaskular dari medulla. Relaksasi memberikan respon melawan masa discharge (pelepasan impuls secara masal) pada respon stres dari sistem saraf simpatis (Aspiani, 2014). Dimana pada sistem saraf simpatis berperan dalam meningkatkan denyut jantung, sedangkan pada saat relaksasi yang bekerja yaitu sistem saraf parasimpatis. Dengan demikian, relaksasi dapat menekan rasa stres, tegang dan cemas dengan cara resiprok (saling berbalasan). Empat elemen dasar agar teknik relaksasi benson berhasil dalam penerapannya adalah lingkungan yang tenang, secara sadar pasien dapat mengendurkan otot-ototnya, pasien dapat memusatkan diri selama 10 15 menit pada ungkapan yang sudah dipilih, dan pasien bersikap pasif terhadap pikiran yang mengganggu (Solehati \& Kosasih, 2015).

\section{METODE PENELITIAN}

Penelitian ini merupakan penelitian kuantitatif yang menggunakan desain penelitian pra-eksperimental dengan rancangan one group pre-post test design (Nursalam, 2016). Responden yang terlibat dalam penelitian ini sebesar 30 penderita yang mengalami hipertensi di Desa Unggahan. Variabel dalam penelitian ini adalah terapi relaksasi benson dan tekanan darah. Teknik pengambilan sampel yang digunakan yaitu non probability sampling dengan teknik purposive sampling. Analisis yang digunakan dalam penelirian ini adalah pretest dan posttest berdistribusi normal, maka akan dilakukan uji (parametric) dengan uji Paired t-test dan jika data berdistribusi tidak normal maka akan dilakukan uji (non parametric) dengan uji Wilcoxon. Penelitian dilakukan pada bulan April-Mei 2018.

\section{HASIL PENELITIAN}

\section{Karakteristik Subyek Penelitian}

Tabel 1. Karakteristik Responden Berdasarkan Usia di Desa Unggahan

\begin{tabular}{ccccccc}
\hline & $\mathbf{N}$ & Mean & Min & Max & SD & 95\% CI \\
\hline Usia & 30 & 62.33 & 41 & 82 & 12.726 & $\begin{array}{c}57.58- \\
67.09\end{array}$ \\
\hline
\end{tabular}

Berdasarkan tabel 1 di atas menunjukkan bahwa rata-rata usia responden adalah 62.33 tahun. Responden memiliki usia tertinggi 82 tahun dan usia terendah 41 tahun.

Tabel 2. Karakteristik Responden Berdasarkan Jenis Kelamin di Desa Unggahan

\begin{tabular}{ccc}
\hline Karakteristik Responden & Jumlah & Persentase (\%) \\
\hline Jenis Kelamin & & \\
\hline Laki-laki & 9 & 30.0 \\
Perempuan & 21 & 70.0 \\
\hline Total & 30 & 100 \\
\hline Pendidikan & & \\
\hline SD & 16 & 53.3 \\
SMP & 0 & 0 \\
SMA & 0 & 0 \\
Perguruan Tinggi & 0 & 0 \\
Tidak Sekolah & 14 & 46.7 \\
\hline Total & 30 & 100 \\
\hline
\end{tabular}


Berdasarkan tabel 2 di atas dapat dilihat bahwa dari 30 total responden sebagian besar responden berjenis kelamin perempuan yaitu 21 orang $(70.0 \%)$ dan sebagian kecil berjenis kelamin laki-laki yaitu 9 orang $(30.0 \%)$. Berdasarkan tabel 2 di atas dapat dilihat bahwa dari 30 total responden sebagian besar responden memiliki riwayat pendidikan SD yaitu 16 orang $(53.3 \%)$ dan sebagian kecil responden Tidak Sekolah yaitu 14 orang $(46.7 \%)$.

Tabel 3. Distribusi Tekanan Darah Sistol Penderita Hipertensi Sebelum Diberikan Terapi Relaksasi Benson di Desa Unggahan

\begin{tabular}{|c|c|c|c|c|c|}
\hline \multirow{12}{*}{$\begin{array}{l}\text { Tekanan } \\
\text { darah } \\
\text { sebelum } \\
\text { diberikan } \\
\text { intervensi }\end{array}$} & $\begin{array}{c}\text { Tekanan } \\
\text { Darah } \\
\text { Sistol }\end{array}$ & Frekuensi & $\begin{array}{c}\text { Persentase } \\
(\%)\end{array}$ & Mean & SD \\
\hline & $<120$ & 0 & 0 & \multirow{4}{*}{149.93} & \multirow{4}{*}{10.563} \\
\hline & $120-139$ & 5 & 16.7 & & \\
\hline & $140-159$ & 21 & 70.0 & & \\
\hline & $\geq 160$ & 4 & 13.3 & & \\
\hline & Total & 30 & 100 & & \\
\hline & $\begin{array}{c}\text { Tekanan } \\
\text { Darah } \\
\text { Diastol }\end{array}$ & Frekuensi & $\begin{array}{c}\text { Persentase } \\
(\%)\end{array}$ & Mean & SD \\
\hline & $<80$ & 0 & 0 & \multirow{4}{*}{89.33} & \multirow{4}{*}{5.162} \\
\hline & $80-89$ & 17 & 56.7 & & \\
\hline & $90-99$ & 13 & 43.3 & & \\
\hline & $\geq 100$ & 0 & 0 & & \\
\hline & Total & 30 & 100 & & \\
\hline \multirow{12}{*}{$\begin{array}{l}\text { Tekanan } \\
\text { darah } \\
\text { setelah } \\
\text { diberikan } \\
\text { intervensi }\end{array}$} & $\begin{array}{c}\text { Tekanan } \\
\text { Darah } \\
\text { Sistol }\end{array}$ & Frekuensi & $\begin{array}{c}\text { Persentase } \\
(\%)\end{array}$ & Mean & SD \\
\hline & $<120$ & 0 & 0 & \multirow{4}{*}{138.97} & \multirow{4}{*}{10.516} \\
\hline & $120-139$ & 19 & 63.3 & & \\
\hline & $140-159$ & 11 & 36.7 & & \\
\hline & $\geq 160$ & 0 & 0 & & \\
\hline & Total & 30 & 100 & & \\
\hline & $\begin{array}{c}\text { Tekanan } \\
\text { Darah } \\
\text { Diastol }\end{array}$ & Frekuensi & $\begin{array}{c}\text { Persentase } \\
(\%)\end{array}$ & Mean & SD \\
\hline & $<80$ & 3 & 10.0 & \multirow{4}{*}{84.07} & \multirow{4}{*}{3.903} \\
\hline & $80-89$ & 27 & 90.0 & & \\
\hline & $90-99$ & 0 & 0 & & \\
\hline & $\geq 100$ & 0 & 0 & & \\
\hline & Total & 30 & 100 & & \\
\hline
\end{tabular}

Berdasarkan tabel 3 di atas dilihat dari 30 responden menunjukkan bahwa tekanan darah sistol sebelum diberikan terapi relaksasi benson, sebagian besar responden tekanan darah sistolnya 140159 yaitu sebanyak 21 responden $(70.0 \%)$, dan yang paling sedikit adalah responden yang tekanan darah sistolnya $\geq 160$ yaitu sebanyak 4 responden (13.3\%). Berdasarkan tabel 3 di atas dilihat dari 30 responden menunjukkan bahwa tekanan darah diastol sebelum diberikan terapi relaksasi benson, sebagian besar responden tekanan darah diastolnya 80-89 yaitu sebanyak 17 responden $(56.7 \%)$, dan yang paling sedikit adalah responden yang tekanan darah diastolnya 90-99 yaitu sebanyak 13 responden (43.3\%).

Berdasarkan tabel 3 menunjukkan bahwa tekanan darah sistol pada penderita hipertensi di Desa Unggahan sebelum diberikan terapi relaksasi benson dari 30 responden rata-rata (Mean) tekanan darahnya adalah 149.93, dengan Standar Deviation 10.563. Sedangkan pada tekanan darah diastol dari 30 responden rata-rata (Mean) tekanan darahnya adalah 89.33, dengan Standar Deviation 5.162.

Berdasarkan tabel 3 di atas dilihat dari 30 responden menunjukkan bahwa tekanan darah sistol setelah diberikan terapi relaksasi benson, sebagian besar responden tekanan darah sistolnya 120139 yaitu sebanyak 19 responden (63.3\%), dan yang paling sedikit adalah responden yang tekanan darah sistolnya 140-159 yaitu sebanyak 11 responden (16.7\%).

Berdasarkan tabel 3 di atas dilihat dari 30 responden menunjukkan bahwa tekanan darah diastol setelah diberikan terapi relaksasi benson, sebagian besar responden tekanan darah diastolnya 80-89 yaitu sebanyak 27 responden $(90.0 \%)$, dan yang paling sedikit adalah responden yang tekanan darah diastolnya $<80$ yaitu sebanyak 3 responden (10.0\%).

Berdasarkan tabel 3 menunjukkan bahwa tekanan darah sistol pada penderita 
hipertensi di Desa Unggahan setelah diberikan terapi relaksasi benson dari 30 responden rata-rata (Mean) tekanan darahnya adalah 138.97, dengan Standar Deviation 10.516. Sedangkan pada tekanan darah diastol dari 30 responden rata-rata (Mean) tekanan darahnya adalah 84.07, dengan Standar Deviation 3.903.

Tabel 4. Hasil Uji Pre dan Post Test dengan menggunakan Uji Paired t-test

\begin{tabular}{|c|c|c|c|c|c|c|}
\hline Data & $\mathbf{N}$ & Mean & $\begin{array}{c}\text { Std. } \\
\text { Deviatio } \\
n\end{array}$ & $\begin{array}{c}\text { Std. } \\
\text { Erro } \\
r \\
\text { Mea } \\
n\end{array}$ & $\bar{t}$ & $\begin{array}{c}\text { Sig. } \\
(2- \\
\text { tailed } \\
)\end{array}$ \\
\hline $\begin{array}{c}\text { Pre- } \\
\text { Post } \\
\text { Sistol } \\
\end{array}$ & $\begin{array}{l}3 \\
0\end{array}$ & $\begin{array}{c}10.96 \\
7\end{array}$ & 4.189 & 0.765 & $\begin{array}{c}14.33 \\
8\end{array}$ & 0.000 \\
\hline $\begin{array}{c}\text { Pre- } \\
\text { Post } \\
\text { Diasto } \\
\text { l }\end{array}$ & $\begin{array}{l}3 \\
0\end{array}$ & 5.267 & 3.151 & 0.575 & 9.156 & 0.000 \\
\hline
\end{tabular}

Berdasarkan tabel 4 dapat dilihat bahwa dari hasil uji statistik yang dilakukan dengan menggunakan uji paired t-test untuk tekanan darah sistol menunjukkan bahwa hasil sig (2-tailed) atau nilai $\mathrm{p}=0,000$, dan pada tekanan darah diastol menunjukkan bahwa hasil sig (2-tailed) atau nilai $\mathrm{p}=0,000$ dengan demikian, nilai $\mathrm{p}$ lebih kecil dari 0,05 $(\mathrm{p}<\alpha)$ maka hipotesis nol $\left(\mathrm{H}_{0}\right)$ ditolak dan hipotesis alternatif $\left(\mathrm{H}_{\mathrm{a}}\right)$ diterima. Sehingga dapat disimpulkan ada Pengaruh Terapi Relaksasi Benson Terhadap Tekanan Darah Pada Penderita Hipertensi Di Desa Unggahan.

\section{PEMBAHASAN}

\section{Tekanan Darah Pada Penderita Hipertensi Sebelum Diberikan Terapi Relaksasi Benson}

Sebelum pemberian perlakuan terapi relaksasi benson pada penderita hipertensi di Desa Unggahan, terlebih dahulu peneliti melakukan komunikasi untuk menumbuhkan hubungan saling percaya antara responden dengan peneliti. Setelah itu peneliti melakukan pengukuran tekanan darah dengan menggunakan tensimeter.

Hasil penelitian menunjukkan bahwa tekanan darah pada penderita hipertensi didapatkan 30 responden yang menjadi subjek penelitian, pada tekanan darah sistol sebelum diberikan terapi relaksasi benson, rentang tekanan sistol 120-139 yaitu sebanyak 5 responden (16.7\%), tekanan sistol 140-159 yaitu sebanyak 21 responden $(70.0 \%)$, dan tekanan sistol $\geq 160$ yaitu sebanyak 4 responden $(13.3 \%)$. Dan rata-rata (Mean) tekanan darahnya adalah 149.93, dengan Standar Deviation 10.563, dan Standar Error Mean 1.929. Sedangkan pada tekanan darah diastol sebelum diberikan terapi relaksasi benson, rentang tekanan diastol 80-89 yaitu sebanyak 17 responden (56.7\%), dan tekanan diastol 90-99 yaitu sebanyak 13 responden (43.3\%). Dan ratarata (Mean) tekanan darahnya adalah 89.33, dengan Standar Deviation 5.162, dan Standar Error Mean 0.942.

Berdasarkan hasil penelitian yang dilakukan pada responden, faktor-faktor yang mempengaruhi peningkatan tekanan darah adalah usia, jenis kelamin, dan pendidikan. Hasil penelitian menunjukkan bahwa hipertensi lebih beresiko terjadi pada usia tua, dan pada jenis kelamin, perempuan lebih beresiko terkena hipertensi dibandingkan dengan laki-laki. Sedangkan pada pendidikan, orang yang pendidikannya lebih rendah cenderung lebih beresiko terkena hipertensi dari pada yang pendidikannya lebih tinggi. Disamping itu ada faktor lain yang menyebabkan peningkatan tekanan darah yaitu obesitas, stres dalam kehidupan sehari-hari, kurang olahraga dan juga pola hidup yang tidak sehat salah satunya yaitu 
asupan garam pada makanan yang terlalu banyak.

Pendapat tersebut sejalan dengan penelitian yang dilakukan oleh Putra dan Ulfah (2016) yang berjudul "Analisis Faktor Risiko Hipertensi di Puskesmas Kelayan Timur Kota Banjarmasin", hasil penelitian menunjukkan bahwa ada hubungan antara kebiasaan makanmakanan asin dengan kejadian hipertensi. Kebiasaan makan-makanan asin berisiko terkena hipertensi 2,898 kali lebih besar dibandingkan dengan yang tidak terbiasa makan-makanan asin untuk terkena hipertensi. Hasil penelitian menunjukkan bahwa dari 212 responden yang kebiasaan makan-makanan asin sebanyak 113 responden $\quad(53,30 \%), \quad$ sedangkan responden yang tidak kebiasaan makanmakanan asin 99 responden $(46,70 \%)$.

Penelitian lain yang mendukung hasil penelitian ini adalah penelitian yang dilakukan oleh Arif, dkk (2013) tentang "Faktor-faktor Yang Berhubungan dengan Kejadian Hipertensi pada Lansia di Pusling Desa Klumpit UPT Puskesmas Gribig Kabupaten Kudus" hasil penelitian menunjukkan bahwa dari 54 responden yang tidak mengalami hipertensi yang mempunyai kebiasaan asupan garam dengan kategori cukup yaitu sebesar 18 responden $(70 \%)$ dan kategori sering sebanyak 9 (30\%). Sedangkan pada responden yang mengalami hipertensi yang mempunyai kebiasaan asupan garam dengan kategori cukup yaitu sebanyak 6 (25\%) dan kategori sering sebanyak 21 (75\%). Hasil penelitian menunjukkan bahwa kebiasaan asupan garam berhubungan dengan kejadian hipertensi pada lansia di Pusling Desa Klumpit UPT Puskesmas Gribig, karena hasil uji Chi Square menunjukkan bahwa nilai $\mathrm{p}$ $(0,001)<0,05$ dan nilai X2 hitung
$(10,667)>$ X2 tabel $(3,84)$. Nilai r 0,124 menunjukkan bahwa hubungan antara keduanya bersifat searah dimana semakin sering kebiasaan asupan garam maka akan semakin berisiko untuk mengalami hipertensi.

\section{Tekanan Darah Pada Penderita Hipertensi Setelah Diberikan Terapi Relaksasi Benson}

Setelah pemberian perlakuan terapi relaksasi benson pada penderita hipertensi di Desa Unggahan selama 2 minggu, frekuensi 2 kali dalam sehari dengan waktu 10 menit, dan selanjutnya dilakukan pengukuran tekanan darah dengan menggunakan tensimeter.

Hasil penelitian menunjukkan hasil bahwa tekanan darah sistol setelah diberikan terapi relaksasi benson, rentang tekanan sistol 120-139 yaitu sebanyak 19 responden (63.3\%), dan tekanan sistol 140-159 yaitu sebanyak 11 responden (16.7\%). Dan rata-rata (Mean) tekanan darahnya adalah 138.97, dengan Standar Deviation 10.516, dan Standar Error Mean 1.920. Sedangkan hasil tekanan darah diastol setelah diberikan terapi relaksasi benson, rentang tekanan diastol $<80$ yaitu sebanyak 3 responden $(10.0 \%)$, dan tekanan diastol 80-89 yaitu sebanyak 27 responden $(90.0 \%)$. Dan rata-rata (Mean) tekanan darahnya adalah 84.07, dengan Standar Deviation 3.903, dan Standar Error Mean 0.713.

Berdasarkan hasil penelitian yang dilakukan pada responden bahwa hasil penelitian menunjukkan adanya penurunan tekanan darah. Responden yang mengalami penurunan tekanan darah dikarenakan serius dan kooperatif dalam mengikuti terapi relaksasi benson, dan mengatur pola hidup yang sehat yaitu mengurangi asupan garam pada makanan. Untuk responden yang belum mengalami 
penurunan tekanan darah di samping karena faktor neurologik atau biokimia tubuh bisa juga disebabkan karena kurangnya konsentrasi dan kurang pemahaman dalam proses pelaksanaan terapi yang diberikan serta faktor kepribadian dari masing-masing responden sehingga menyebabkan terapi kurang maksimal.

Menurut Wijaya \& Putri (2013) menyatakan bahwa penatalaksanaan hipertensi dengan non farmakologi terdiri dari berbagai macam cara modifikasi gaya hidup untuk menurunkan tekanan darah salah satunya yaitu dengan mengurangi asupan natrium dapat dilakukan dengan cara diet rendah garam yaitu tidak lebih dari $100 \mathrm{mmol} / \mathrm{hari}$. Dengan mengurangi asupan garam sampai kurang dari 2300 mg (1 sendok teh) per hari menjadi 1150 mg ( $1 / 2$ sendok teh $)$ per hari dapat menurunkan tekanan sistolik sekitar 5 mmHg dan pada tekanan diastolik sekitar 2,5 $\mathrm{mmHg}$.

Meditasi dan relaksasi menyebabkan akan terjadi penurunan konsumsi oksigen, output $\mathrm{CO}_{2}$, ventilasi selular, frekuensi napas, dan kadar laktat sebagai indikasi dalam penurunan tingkat stres, selain itu ditemukan bahwa $\mathrm{PO}_{2}$ atau konsentrasi oksigen di dalam darah tetap konstan, bahkan meningkat sedikit (Solehati \& Kosasih, 2015).

Penelitian yang dilakukan oleh Aryana \& Novitasari (2013) terapi relaksasi benson berpengaruh terhadap penurunan tingkat stres lansia. Pada hasil penelitian menunjukkan bahwa tingkat stres lansia sebelum diberikan relaksasi benson pada kelompok intervensi adalah 2 orang $(13,3 \%)$ yang mengalami stres ringan, 10 orang $(66,7 \%)$ yang mengalami stres sedang, dan 3 orang $(20,0 \%)$ yang mengalami stres berat. Kemudian untuk kelompok kontrol adalah 2 orang (13,3\%) yang mengalami stres ringan, 11 orang $(73,4 \%)$ yang mengalami stres sedang, dan 2 orang $(13,3 \%)$ yang mengalami stres berat. Setelah diberikan relaksasi benson pada kelompok intervensi yaitu 9 orang $(60,0 \%)$ yang mengalami stres ringan, dan 6 orang $(40,0 \%)$ yang mengalami stres sedang. Kemudian untuk kelompok kontrol yaitu 3 orang $(20,0 \%)$ yang mengalami stres ringan, 10 orang $(66,7 \%)$ yang mengalami stres sedang, dan 2 orang $(13,3 \%)$ yang mengalami stres berat.

Penelitian yang dilakukan oleh Rasubala, dkk (2017) terapi relaksasi benson berpengaruh terhadap skala nyeri pada pasien post operasi. Penelitian ini dilakukan pada 16 responden, setelah pemberian perlakuan terapi relaksasi benson selama 3 kali pertemuan selama 15-30 menit, tingkat nyeri pada pasien post operasi sebelum diberikan terapi pada tingkat nyeri sedang (4-6) sebanyak 8 responden $(50 \%)$ dan tingkat nyeri berat (7-9) sebanyak 8 responden (50\%). Kemudian setelah diberikan terapi pada tingkat nyeri ringan (1-3) sebanyak 9 responden $(56,2 \%)$, dan pada tingkat nyeri sedang (4-6) sebanyak 7 responden $(43,8 \%)$.

\section{Menganalisis Pengaruh Terapi Relaksasi Benson Terhadap Tekanan Darah Pada Penderita Hipertensi Di Desa Unggahan}

Setelah dilakukan uji statistik yaitu uji paired t-test dengan menggunakan 30 responden, untuk tekanan darah sistol menunjukkan bahwa hasil sig (2-tailed) atau nilai $\mathrm{p}=0,000$, dan pada tekanan darah diastol menunjukkan bahwa hasil sig (2-tailed) atau nilai $\mathrm{p}=0,000$ dengan demikian, nilai $\mathrm{p}$ lebih kecil dari 0,05 $(\mathrm{p}<\alpha)$ maka hipotesis nol $\left(\mathrm{H}_{0}\right)$ ditolak dan 
hipotesis alternatif $\left(\mathrm{H}_{\mathrm{a}}\right)$ diterima. Hal ini menunjukkan ada Pengaruh Terapi Relaksasi Benson Terhadap Tekanan Darah Pada Penderita Hipertensi Di Desa Unggahan.

Melihat pengaruh terapi relaksasi benson terhadap tekanan darah pada penderita hipertensi di Desa Unggahan dengan jalan membandingkan hasil ratarata tekanan darah sistol dan diastol sebelum dan setelah intervensi terapi relaksasi benson diberikan. Hasil rata-rata (mean) tekanan darah sistol dan diastol sebelum diberikan intervensi terapi relaksasi benson yaitu 149.93 dan 89.33 Dan setelah diberikan intervensi terapi relaksasi benson menjadi 138.97 dan 84.07. Penelitian ini membuktikan adanya pengaruh terapi relaksasi benson terhadap tekanan darah pada penderita hipertensi di Desa Unggahan.

Hal ini didukung dengan hasil penelitian yang dilakukan oleh Juwita, dkk (2016) tentang "Pengaruh Terapi Relaksasi Benson Terhadap Kadar Gula Darah pada Lansia dengan Diabetes dijalan Dinoyo Tangsi III RW II Kelurahan Keputeran, Kecamatan Tegalsari, Surabaya". Hasil penelitian menunjukan bahwa sebelum diberikan terapi didapatkan hasil mean pada kelompok perlakuan yaitu $263.32 \pm 66.53$ dan pada kelompok kontrol yaitu 276 \pm 71.56 . Sedangkan setelah diberikan terapi didapatkan hasil mean pada kelompok perlakuan yaitu $201.37 \pm 50.93$ dan pada kelompok kontrol yaitu $257 \pm 63.54$. Pada penelitian ini juga dapat diketahui bahwa didapatkan hasil penelitian dengan uji statistik dengan paired t-test dan di dapatkan hasil $\mathrm{p}=0.001$ pada kelompok perlakuan dan $\mathrm{p}=0.005$ pada kelompok kontrol. Sehingga dapat disimpulkan bahwa terjadi penurunan kadar gula darah pada kelompok perlakuan, sehingga dengan demikian terbuktilah hipotesis bahwa ada pengaruh terapi relaksasi benson terhadap kadar gula darah pada lansia dengan diabetes.

Hipertensi adalah suatu keadaan dimana tekanan darah meningkat secara abnormal dan terjadi secara terus menerus pada beberapa kali pemeriksaan tekanan darah yang disebabkan oleh satu faktor maupun beberapa faktor risiko yang tidak berjalan sebagaimana mestinya dalam mempertahankan tekanan darah secara normal (Wijaya \& Putri, 2013).

Salah satu penatalaksanaan hipertensi dengan non farmakologi yaitu dengan metode relaksasi. Terapi relaksasi benson dengan tekanan darah adalah terapi yang diberikan kepada penderita hipertensi yang bertujuan untuk mengatasi tekanan darah tinggi dan ketidakteraturan denyut jantung. Pada keadaan relaksasi menyebabkan terjadi penurunan rangsangan emosional dan area pengatur fungsi kardiovaskular seperti hipotalamus posterior yang akan menurunkan tekanan darah, sedangkan rangsangan pada area pre optik menimbulkan efek penurunan arteri dan frekuensi denyut jantung yang dijalarkan melalui pusat kardiovaskular dari medulla. Relaksasi memberikan respon melawan masa discharge (pelepasan impuls secara masal) pada respon stres dari sistem saraf simpatis (Aspiani, 2014b). Dimana pada sistem saraf simpatis berperan dalam meningkatkan denyut jantung, kemudian pada saat dalam keadaan berelaksasi yang bekerja yaitu sistem saraf parasimpatis. Dengan demikian, dalam keadaan berelaksasi juga dapat menekan rasa stres, tegang dan cemas. 
Hal tersebut didukung oleh penelitian yang dilakukan oleh Kurniasari \& Kustanti (2016) tentang "The Effect Benson Relaxation Technique with Anxiety In Hemodyalisis Patients In Yogyakarta". Pada hasil penelitian menunjukkan bahwa tingkat kecemasan pada responden sebelum dan sesudah diberikan relaksasi benson selama 2 minggu setiap hari pada kelompok intervensi adalah 21,93 dan 13,57 dengan rata-rata 8,36. Sedangkan pada kelompok kontrol sebelum dan sesudah diberikan relaksasi benson yaitu 17,19 dan 12,94 dengan rata-rata 4,25. Sehingga pada penelitian ini menunjukkan bahwa ada penurunan yang signifikan dalam tingkat kecemasan pada kelompok intervensi $\mathrm{p}=$ $0,001 \quad(\mathrm{p}<0,05)$ dan pada kelompok kontrol $p=0,014(p<0,05)$.

\section{KESIMPULAN DAN SARAN}

Berdasarkan hasil tekanan darah responden setelah diberikan terapi relaksasi benson, sebagian besar responden yang tekanan darah sistolnya 120-139 sebanyak 19 responden (63.3\%), dan yang paling sedikit adalah responden yang tekanan darah sistolnya 140-159 sebanyak 11 responden (16.7\%). Dan ratarata (Mean) tekanan darahnya adalah 138.97, dengan Standar Deviation 10.516. Sedangkan sebagian besar responden yang tekanan darah diastolnya 80-89 sebanyak 27 responden $(90.0 \%)$, dan yang paling sedikit adalah responden yang tekanan darah diastolnya $<80$ sebanyak 3 responden (10.0\%). Dan rata-rata (Mean) tekanan darahnya adalah 84.07. Hasil uji analisa data dengan menggunakan uji Paired t-test, untuk tekanan darah sistol dan diastol menunjukkan bahwa hasil sig (2-tailed) atau nilai $\mathrm{p}=0,000$ karena nilai $\mathrm{p}$ lebih kecil dari $0,05(\mathrm{p}<\alpha)$ maka hipotesis nol $\left(\mathrm{H}_{0}\right)$ ditolak dan hipotesis alternatif $\left(\mathrm{H}_{\mathrm{a}}\right)$ diterima. Sehingga dapat disimpulkan ada Pengaruh Terapi Relaksasi Benson Terhadap Tekanan Darah Pada Penderita Hipertensi Di Desa Unggahan.

\section{DAFTAR RUJUKAN}

Arif, D., Rustono., \& Hartinah, D. (2013). Faktor-faktor Yang Berhubungan Dengan Kejadian Hipertensi Pada Lansia Di Pusling Desa Klumpit UPT Puskesmas Gribig Kabupaten Kudus. JIKK, 4(2), 18-34.

Aryana, K.O., \& Novitasari, D. (2013). Pengaruh Tehnik Relaksasi

Benson Terhadap Penurunan Tingkat Stres Lansia Di Unit Rehabilitas Sosial Wening Wardoyo Ungaran. Jurnal Keperawatan Jiwa, 1(2), 186-195.

Aspiani, R.Y. (2014a). Buku Ajar Keperawatan Gerontik. Jilid Pertama. Jakarta: CV. Trans Info Media.

Juwita, L., Prabasari, N.A., \& Manungkalit, M. (2016). Pengaruh Terapi Relaksasi Benson Terhadap Kadar Gula Darah Pada Lansia Dengan Diabetes. Jurnal Ners LENTERA, 4(1), 6-14.

Kemenkes. (2014). Pusat Data Dan Informasi Kementrian Kesehatan RI. Jakarta.

Kurniasari, A.N., \& Kustanti, A. (2016). The Effect Benson Relaxation Technique With Anxiety In Hemodyalisis Patients In Yogyakarta. Indonesian Journal Of Nursing Practices, 1(1), 40-47.

Larasiska, A., \& Priyantari, W. (2017). Menurunkan Tekanan Darah dengan Cara Mudah Pada Lansia. Indonesian Journal of Nursing Practices, 1(2), 55-63. 
Maulinda, I., Candrawati, E., \& Adi W., R.C. (2017). Pengaruh Terapi Relaksasi Benson Terhadap Kualitas Tidur Lansia Di Posyandu Permadi Tlogomas Kota Malang. Nursing News, 2(3), 580-587.

Nursalam. (2016). Metodologi Penelitian Ilmu Keperawatan. Edisi 4. Jakarta: Salemba Medika.

Putra, A.M.P \& Ulfah, A. (2016). Analisis Faktor Risiko Hipertensi Di Puskesmas Kelayan Timur Kota Banjarmasin. Jurnal Ilmiah Ibnu Sina, 1(2), 256-264.

Rasubala, G.F., Kumaat, L.T., \& Mulyadi. (2017). Pengaruh Teknik Relaksasi Benson Terhadap Skala Nyeri Pada Pasien Post Operasi Di RSUP. PROF. DR. R.D. Kandou Dan RS TK.III R.W. Mongisidi Teling Manado. E-Journal Keperawatan. 5(1).

Solehati, T., \& Kosasih, C.E. (2015). Konsep \& Aplikasi Relaksasi. Bandung: Refika Aditama.

Suiraoka, IP. (2012). Penyakit Degeneratif : Mengenal, Mencegah dan Mengurangi Faktor Risiko 9 Penyakit Degeneratif. Yogyakarta: Nuha Medika.

Wijaya, A.S., \& Putri, Y.M. (2013). Keperawatan Medikal Bedah : Keperawatan Dewasa. Yogyakarta: Nuha Medika. 